\title{
Streptomyces fenghuangensis sp. nov., isolated from seawater
}

\author{
Correspondence \\ Honghui Zhu \\ zhuhonghui66@yahoo.com.cn
}

\author{
Honghui Zhu, ${ }^{1} \dagger$ Shumei Jiang, ${ }^{2} \dagger$ Qing Yao, ${ }^{3}$ Yonghong Wang, ${ }^{1}$ \\ Meibiao Chen, ${ }^{1}$ Yuanliang Chen ${ }^{1}$ and Jun Guo ${ }^{1}$
}

\author{
${ }^{1}$ Guangdong Provincial Microbial Culture Collection and Application Key Laboratory, Guangdong \\ Institute of Microbiology, Guangzhou, Guangdong 510070, PR China \\ ${ }^{2}$ South China Sea Institute of Oceanology, Chinese Academy of Sciences, Guangzhou, Guangdong \\ 510301, PR China \\ ${ }^{3}$ South China Agricultural University, Guangzhou, Guangdong 510642, PR China
}

\begin{abstract}
An actinomycete, designated strain GIMN4.003 ${ }^{\top}$, was isolated from seawater collected in Sanya, China. It produced white aerial mycelium and yellow substrate mycelium on Gause's synthetic agar medium no. 1. The substrate mycelium colour was not sensitive to $\mathrm{pH}$. Scanning electron microscopy observations revealed that GIMN4.003 ${ }^{\top}$ produced straight to flexuous spore chains of rough to warty spores. LL-Diaminopimelic acid was present in the cell-wall hydrolysate. Based on chemotaxonomy and morphological features, strain GIMN4.003 ${ }^{\top}$ was identified as a member of the genus Streptomyces. Melanin was not produced. No antimicrobial activity was detected against Escherichia coli, Pseudomonas aeruginosa, Bacillus subtilis, Penicillium citrinum or Candida albicans. Analysis of the 16S rRNA gene sequence revealed that the highest sequence similarity was to Streptomyces radiopugnans R97 ${ }^{\top}$ (99.0\%). However, DNA relatedness between GIMN4.003 ${ }^{\top}$ and S. radiopugnans DSM $41901^{\top}$ was low $(41.24 \pm 1.47 \%)$. Furthermore, the morphological, physiological and biochemical characteristics of strain GIMN4.003 ${ }^{\top}$ were different from those of $S$. radiopugnans DSM $41901^{\top}$ and the type strains of other closely related Streptomyces species. On the basis of its physiological and molecular properties, it is evident that strain GIMN4.003 ${ }^{\top}$ (=CCTCCM $208215^{\top}=$ NRRL B-24801 ${ }^{\top}$ ) represents the type strain of a novel species within the genus Streptomyces, for which the name Streptomyces fenghuangensis sp. nov. is proposed.
\end{abstract}

The marine biosphere is one of the richest habitats of micro-organisms. Marine microbes, particularly Streptomyces species, are considered important for their secondary metabolites and enzymes with novel properties (Sabu, 2003). Marine streptomycetes are widely recognized as a potential source of new drug candidates (Jensen et al., 2005). Members of the genus Streptomyces are known to produce a wide variety of bioactive compounds, antibiotics and enzymes (Koshy et al., 1997; Balagurunathan, 2004). The isolation and screening of novel streptomycetes as sources of novel natural products, bioactive compounds and therapeutic enzymes are therefore essential. Strain GIMN4.003 ${ }^{\mathrm{T}}$ was isolated from seawater collected in Sanya, China, in August 2007. Seawater samples were collected from five stations at Sanya and were stored in sterile 11

†These authors contributed equally to this work.

Abbreviations: DAP, diaminopimelic acid; ISP, International Streptomyces Project.

The GenBank/EMBL/DDBJ accession number for the $16 \mathrm{~S}$ rRNA gene sequence of strain GIMN4.003 ${ }^{\top}$ is GU356598. bottles. The samples were stored under environmental conditions and processed within $24 \mathrm{~h}$ in a laboratory; water samples $(1 \mathrm{ml})$ were inoculated onto Gause's synthetic agar medium no. 1 (Atlas, 1993), prepared with artificial seawater, and incubated for 5-7 days at $28{ }^{\circ} \mathrm{C}$.

International Streptomyces Project (ISP) media were prepared according to the methods of Shirling \& Gottlieb (1966). Morphological and physiological characteristics were determined as recommended by Williams et al. (1989). Morphological observations of spores and mycelium were conducted by light microscopy (Leica DM RAR) and scanning electron microscopy (Hitachi S-3000N). Physiological tests were carried out at $28{ }^{\circ} \mathrm{C}$ (unless otherwise indicated). D-Glucose, sucrose, D-fructose, Dxylose, L-arabinose, inositol, mannitol, L-rhamnose and raffinose were tested as sole carbon sources at $0.1 \%(\mathrm{w} / \mathrm{v})$; all carbon sources for carbon-utilization tests were filtersterilized. Colour determination was referenced against the Methuen Handbook of Colour (Kornerup \& Wanscher, 1978). 
Analysis of the diaminopimelic acid (DAP) isomer and the whole-cell sugar composition followed the procedure described by Hasegawa et al. (1983) with the exception that dried cells were used instead of colonies from agar plates. Fully hydrolysed cell-wall material was prepared from approximately $10 \mathrm{mg}$ (dry weight) cells by the hot trichloroacetic acid trypsin rapid-screening method of Schleifer \& Kandler (1972). Fatty acid methyl esters were prepared by the trimethyl sulphonium hydroxide method (Butte, 1983) and analysed by GC (6890; Hewlett Packard) using the Microbial Identification software package (Sasser, 1990). Menaquinones were extracted according to the method of Collins et al. (1977) and analysed by HPLC (Kroppenstedt, 1985). The genomic DNA base composition of strain GIMN4.003 ${ }^{\mathrm{T}}$ was determined in $0.1 \times$ SSC by the method of Mandel \& Marmur (1968). Genomic DNA was extracted (Cui et al., 2001) and the 16S rRNA gene was amplified by PCR using universal bacterial $16 \mathrm{~S}$ rRNA gene primers. The forward primer F27 (5'-AGAGTTTGATCCTGGCTCAG-3') and reverse primer 1522R (5'-AAGGAGGTGATCCAGCCGCA-3') were adapted from primers $\mathrm{pA}$ and $\mathrm{pH}$ of Edwards et al. (1989). The $16 \mathrm{~S}$ rRNA gene was sequenced with an automated capillary DNA sequencing system (ABI 3730) and ABI Big Dye Terminator cycle sequencing kit. DNA relatedness studies were done by the method described by De Ley et al. (1970).

Good growth was observed on yeast extract/malt extract agar (ISP 2), Gause's synthetic agar medium no. 1, glucoseasparagine agar (Waksman, 1961) and Czapek's solution agar (Nakase, 1992). Moderate growth was observed on oatmeal agar (ISP 3), glycerol-asparagine agar (ISP 5) and starch agar (Waksman, 1961). Poor growth was observed on inorganic salts/starch agar (ISP 4). Diffusible pigments were produced only on ISP 5 medium and Gause's synthetic agar medium no. 1 (Table 1).

Morphological features were observed on Gause's synthetic agar medium no. 1 (Xiao et al., 2009) and ISP 2. Cultures were incubated for 2 weeks at $28{ }^{\circ} \mathrm{C}$. Strain GIMN4.003 had characteristics typical of the genus Streptomyces. Microscope studies revealed a straight to flexuous mycelium without verticils. The aerial mycelium produced straight to flexuous spore chains. Spores were rough to warty (Fig. 1). The colour of the spore mass was grey, and the strain produced white aerial mycelium and yellow to yellowish-white vegetative mycelium. Melanin was not produced on tyrosine agar (ISP 7).

Chemotaxonomic tests showed that the cell wall contained LL-DAP, indicating that it was of cell-wall type I (Lechevalier \& Lechevalier, 1970). Whole-cell hydrolysates contained glucose. The predominant menaquinones were MK-10 $\left(\mathrm{H}_{2}\right)$ $(63.22 \%)$, MK-9 $\left(\mathrm{H}_{8}\right)(33.23 \%), \mathrm{MK}-10\left(\mathrm{H}_{4}\right)(2.16 \%)$ and MK-9 $\left(\mathrm{H}_{6}\right)(1.01 \%)$. Fatty acid analysis showed that strain GIMN4.003 ${ }^{\mathrm{T}}$ contained straight-chain and iso- and anteisobranched fatty acids; the major cellular fatty acids $(>4 \%)$ were iso- $\mathrm{C}_{16: 0}(39.30 \%)$, anteiso- $\mathrm{C}_{15: 0}(24.20 \%)$, iso- $\mathrm{C}_{14: 0}$ $(12.10 \%)$, iso- $\mathrm{C}_{16: 1} \mathrm{H}(6.21 \%)$, anteiso- $\mathrm{C}_{17: 0}(5.43 \%)$ and iso- $\mathrm{C}_{15: 0}(4.63 \%)$. The $\mathrm{G}+\mathrm{C}$ content of the genomic DNA was $72.94 \mathrm{~mol} \%$.

The morphological and physiological characteristics of strain GIMN4.003 ${ }^{\mathrm{T}}$, for example its cell-wall type, wholecell sugar pattern, fatty acid profile and menaquinones, were in line with its assignment to the genus Streptomyces (Williams et al., 1989; Manfio et al., 1995).

A partial 16S rRNA gene sequence (1427 nt) was determined for strain GIMN4.003 ${ }^{\mathrm{T}}$. Sequence comparison with representatives of the family Streptomycetaceae confirmed that strain GIMN4.003 ${ }^{\mathrm{T}}$ is closely related to members of the genus Streptomyces (BLAST analysis; Altschul et al., 1997). It was $97.0-99.67 \%$ similar to the 16S rRNA gene sequences of Streptomyces species. High 16S rRNA gene sequence similarity was found with Streptomyces radiopugnans $\mathrm{R} 97^{\mathrm{T}}$ (GenBank accession no. DQ912930; 99.0\%). Streptomyces macrosporus DSM $41449^{\mathrm{T}}$ (AB184616; $98.1 \%$ similarity over 1399 bases) and Streptomyces megasporus NBRC $14749^{\mathrm{T}}$ (AB184617; $97.0 \%$ similarity over 1394 bases) showed lower

Table 1. Cultural characteristics of strain GIMN4.003 ${ }^{\top}$ on various media

ISP media (Shirling \& Gottlieb, 1966) are described in the text. The colour of mycelium was compared according to Kornerup \& Wanscher (1978). The strain gave the same result for growth and for sporulation on all tested media.

\begin{tabular}{|c|c|c|c|c|}
\hline \multirow[t]{2}{*}{ Medium } & \multirow{2}{*}{$\begin{array}{l}\text { Growth and } \\
\text { sporulation }\end{array}$} & \multicolumn{2}{|c|}{ Colour of: } & \multirow{2}{*}{$\begin{array}{c}\text { Production of diffusible } \\
\text { pigments }\end{array}$} \\
\hline & & Aerial mycelium & Substrate mycelium & \\
\hline ISP 2 & Good & White & Yellowish white & - \\
\hline ISP 3 & Moderate & White & Grey & - \\
\hline ISP 4 & Poor & None & Greyish white & - \\
\hline ISP 5 & Moderate & Greyish white & Yellowish white & Blue \\
\hline Glucose-asparagine agar & Good & White & Yellowish white & - \\
\hline Gause's synthetic agar medium no. 1 & Good & White & Yellow & Pale yellow \\
\hline Czapek's agar & Good & Yellowish white & White & - \\
\hline Starch agar & Moderate & Orange-yellow & Yellow & - \\
\hline
\end{tabular}




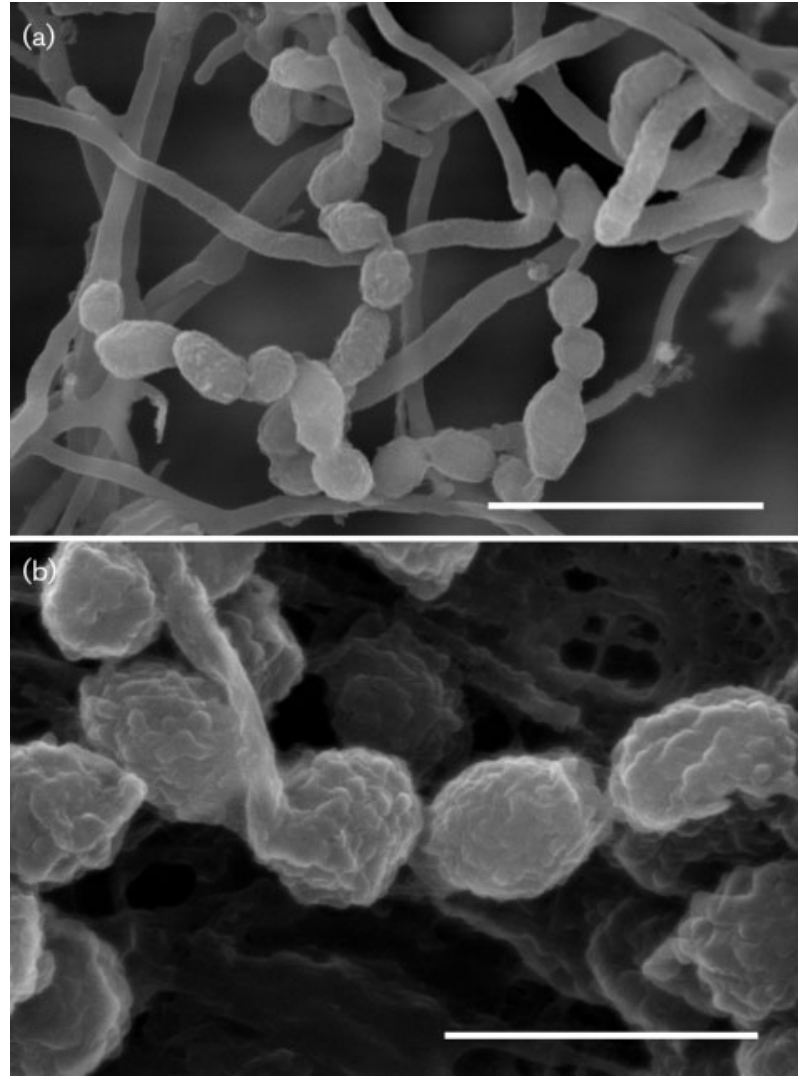

Fig. 1. Scanning electron micrographs of strain GIMN4.003 showing straight to flexuous (rectiflexibiles) spore chains of rough to warty spores after growth on yeast extract/malt extract agar (ISP 2) for 14 days at $28^{\circ} \mathrm{C}$. Bars, $5 \mu \mathrm{m}$ (a) and $2 \mu \mathrm{m}$ (b).

similarity; similarity to the $16 \mathrm{~S}$ rRNA gene sequences of other Streptomyces species was less than $97 \%$.

A phylogenetic tree of $16 \mathrm{~S}$ rRNA gene sequences of members of the genus Streptomyces was constructed using the neighbour-joining method (Saitou \& Nei, 1987) with CLUSTAL W version 1.81 (Thompson et al., 1994) and MEGA version 3.1 (Kumar et al., 2008) (Fig. 2). For the neighbourjoining analysis, a distance matrix was calculated according to Kimura's two-parameter correction model. The minimum-evolution and maximum-parsimony methods were also used for tree reconstruction. Fig. 2 shows the close phylogenetic relationship of strain GIMN4.003 ${ }^{\mathrm{T}}$ with members of the genus Streptomyces.

Phenotypic properties of strain GIMN4.003 ${ }^{\mathrm{T}}$ were compared with those of its closest phylogenetic neighbours (Table 2) by using procedures described above. The results showed that GIMN4.003 ${ }^{\mathrm{T}}$ has some characteristics that differed from those of its closest relatives; S. radiopugnans DSM $41901^{\mathrm{T}}, S$. macrosporus NBRC $14748^{\mathrm{T}}$ and S. megasporus NBRC $14749^{\mathrm{T}}$ differed from strain GIMN4.003 ${ }^{\mathrm{T}}$ in that they produced spiral spore chains and that diffusible pigments were not formed on any of the tested media (Table 2).
It is evident from the phylogenetic analysis (Fig. 2) that strain GIMN4.003 ${ }^{\mathrm{T}}$ forms a distinct phyletic line together with $S$. radiopugnans $\mathrm{R}^{\mathrm{T}}{ }^{\mathrm{T}}$, a relationship that is supported by both of the other tree-making algorithms employed and by a $91 \%$ bootstrap value in the neighbour-joining analysis. Despite the higher 16S rRNA gene sequence similarity between GIMN4.003 ${ }^{\mathrm{T}}$ and S. radiopugnans $\mathrm{R}^{\mathrm{T}}{ }^{\mathrm{T}}$, DNA relatedness between strain GIMN4.003 ${ }^{\mathrm{T}}$ and S. radiopugnans DSM $41901^{\mathrm{T}}$ was found to be $41.24 \pm 1.47 \%$, a value far below the $70 \%$ cut-off point recommended for the delineation of genomic species (Wayne et al., 1987). DNA-DNA hybridization studies therefore confirmed that strain GIMN4.003 ${ }^{\mathrm{T}}$ represents a novel species within the genus Streptomyces. The result is in agreement with the results of the 16S rRNA gene sequence analyses.

Furthermore, S. radiopugnans DSM $41901^{\mathrm{T}}$ also differs from the new isolate in that it lacked characteristic sugars, and formed white to pale-grey aerial spore mass on Gause's synthetic agar medium no. 1 and yeast extract-malt extract (ISP 2) and pale-yellow aerial spore mass on glycerolasparagine agar (ISP 5). Substrate mycelium was grey to greyish-white on Gause's synthetic agar medium no. 1 and ISP 2, ISP 3, ISP 4, ISP 5 (Table 2).

The genotypic and phenotypic data presented clearly demonstrate that strain GIMN4.003 ${ }^{\mathrm{T}}$ represents a novel species of the genus Streptomyces, for which the name Streptomyces fenghuangensis sp. nov. is proposed.

\section{Description of Streptomyces fenghuangensis sp. nov.}

Streptomyces fenghuangensis (feng.hu.ang.en'sis. N.L. masc. adj. fenghuangensis pertaining to Fenghuang, where the seawater was collected from which the type strain was isolated).

Aerobic, Gram-stain-positive, catalase-positive actinomycete that forms an extensively branched substrate mycelium which carries aerial hyphae that differentiate into straight to flexuous chains of spores with rough to warty surfaces. Milk coagulation, milk peptonization and starch hydrolysis are negative. Good growth on yeast extract/malt extract agar (ISP 2), Gause's synthetic agar medium no. 1, glucoseasparagine agar and Czapek's solution agar and moderate growth on oatmeal agar (ISP 3), glycerol-asparagine agar (ISP 5) and starch agar. Poor growth on inorganic salts/ starch agar (ISP 4). White aerial mycelium is formed on ISP 2, ISP 3, glucose-asparagine agar and Gause's synthetic agar medium no. 1. Greyish-white, yellowish-white and orange-white aerial mycelium is formed on ISP 5, Czapek's agar and starch agar, respectively. Substrate mycelium is white on Czapek's agar, yellow on Gause's synthetic agar medium no. 1 and starch agar, yellowish white on ISP 2, ISP 5 and glucose-asparagine agar, grey on ISP 3 and greyish white on ISP 4 . Blue diffusible pigment is formed on ISP 5. Melanin pigment is not produced on ISP 7. DGlucose, D-fructose, inositol, mannitol and L-arabinose are utilized as sole carbon sources. $\mathrm{H}_{2} \mathrm{~S}$ is not produced. The cell wall contains LL-DAP (cell-wall type I) and glucose is detected as a diagnostic sugar in the whole-cell sugar 


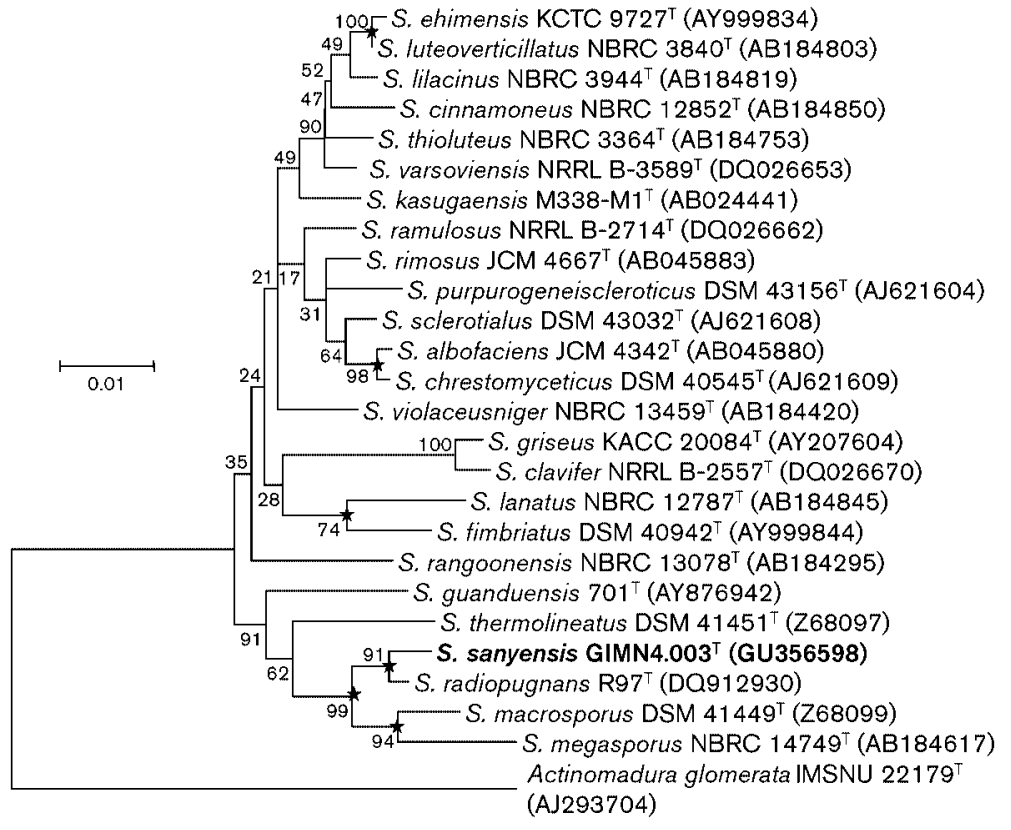

Fig. 2. Unrooted neighbour-joining tree constructed from 16S rRNA gene sequences, showing phylogenetic relationships between strain GIMN4.003 ${ }^{\top}$ and related Streptomyces species belonging to the major, minor and single-member clusters defined by Williams et al. (1983). Actinomadura glomerata IMSNU $22179^{\top}$ was used as the outgroup. Bootstrap values (expressed as percentages of 1000 replications) greater than $50 \%$ are given at nodes. The minimum evolution and maximumparsimony methods were also used for tree reconstruction. Branches marked with an asterisk were conserved in all methods used. Bar, $0.01 \%$ sequence divergence.

Table 2. Phenotypic properties of strain GIMN4.003 ${ }^{\top}$ and its phylogenetic neighbours

Data were obtained in this study under the same conditions. +, Positive; w, weakly positive; -, negative; ai, anteiso-branched; i, iso-branched.

\begin{tabular}{|c|c|c|c|c|}
\hline Characteristic & Strain GIMN4.003 ${ }^{\mathrm{T}}$ & $\begin{array}{l}\text { S. radiopugnans } \\
\text { DSM } 41901^{\mathrm{T}}\end{array}$ & $\begin{array}{l}\text { S. macrosporus } \\
\text { NBRC } 14748^{\mathrm{T}}\end{array}$ & $\begin{array}{l}\text { S. megasporus } \\
\text { NBRC } 14749^{\mathrm{T}}\end{array}$ \\
\hline \multicolumn{5}{|l|}{$\begin{array}{l}\text { Colour of spore mass/ } \\
\text { substrate mycelium on: }\end{array}$} \\
\hline ISP 2 & Grey/yellowish white & White/greyish white & Light grey/greyish grey & None/yellowish grey \\
\hline ISP 3 & Pinkish white/grey & None/greyish white & Olive/grey & None/greyish white \\
\hline ISP 4 & Pale yellow/greyish white & None/grey & None/greyish white & None/white \\
\hline ISP 5 & Greyish white/yellowish white & Pale yellow/greyish white & White/white & Pale white/pale yellow \\
\hline $\begin{array}{l}\text { Spore-surface } \\
\text { ornamentation }\end{array}$ & Rough to warty & Rough to warty & Warty & Warty \\
\hline Spore-chain morphology & Straight to flexuous & Spiral & Spiral & Spiral \\
\hline $\begin{array}{l}\text { Colour of diffusible } \\
\text { pigment on ISP } 5\end{array}$ & Blue & None & None & None \\
\hline \multicolumn{5}{|l|}{$\begin{array}{l}\text { Growth on sole carbon } \\
\text { sources }\end{array}$} \\
\hline L-Rhamnose & - & + & + & $\mathrm{w}$ \\
\hline D-Glucose & + & - & + & + \\
\hline Sucrose & - & - & + & - \\
\hline D-Fructose & + & - & + & - \\
\hline Raffinose & - & - & - & + \\
\hline Mannitol & + & + & - & - \\
\hline D-Xylose & - & + & + & - \\
\hline L-Arabinose & + & + & + & $\mathrm{w}$ \\
\hline Inositol & + & - & + & + \\
\hline $\begin{array}{l}\text { Major cellular fatty } \\
\text { acids }(>4 \%)\end{array}$ & $\begin{array}{l}\text { i- } C_{16: 0}(39.3 \%), \text { ai- } C_{15: 0} \\
(24.2 \%), i-C_{14: 0}(12.1 \%) \\
\text { i- } C_{16: 1} \text { H }(6.2 \%), \text { ai- } C_{17: 0} \\
\quad(5.4 \%), i-C_{15: 0}(4.6 \%)\end{array}$ & $\begin{array}{c}\mathrm{i}-\mathrm{C}_{16: 0}(35.0 \%), \text { ai- } \mathrm{C}_{15: 0} \\
(15.6 \%), \text { ai- }-\mathrm{C}_{17: 0} \\
(13.5 \%), \mathrm{i}-\mathrm{C}_{15: 0}(9.9 \%), \\
\text { i- } \mathrm{C}_{16: 1} \mathrm{H}(8.3 \%), \\
\text { ai- } \mathrm{C}_{17: 1} \omega 9 \mathrm{c}(4.5 \%)\end{array}$ & $\begin{array}{c}\mathrm{i}-\mathrm{C}_{16: 0}(38.8 \%), \text { ai- } \mathrm{C}_{15: 0} \\
(16.0 \%), \mathrm{i}-\mathrm{C}_{16: 1} \mathrm{H} \\
(11.6 \%), \mathrm{i}-\mathrm{C}_{14: 0}(8.9 \%), \\
\text { ai- } \mathrm{C}_{17: 0}(6.6 \%), \mathrm{i}-\mathrm{C}_{15: 0} \\
(6.1 \%)\end{array}$ & $\begin{array}{c}\mathrm{i}-\mathrm{C}_{16: 0}(42.5 \%), \text { ai- }-\mathrm{C}_{15: 0} \\
(12.5 \%), \mathrm{i}-\mathrm{C}_{16: 1} \mathrm{H} \\
(10.0 \%), \mathrm{i}-\mathrm{C}_{15: 0}(10.0 \%), \\
\text { ai- } \mathrm{C}_{17: 0}(8.0 \%), \mathrm{i}-\mathrm{C}_{14: 0} \\
(5.4 \%)\end{array}$ \\
\hline
\end{tabular}


hydrolysate. The predominant menaquinones are MK-10 $\left(\mathrm{H}_{2}\right)$, MK-9 $\left(\mathrm{H}_{8}\right)$, MK-10 $\left(\mathrm{H}_{4}\right)$ and MK-9 $\left(\mathrm{H}_{6}\right)$. The type strain contains straight-chain and iso- and anteisobranched fatty acids and a proportion of unsaturated fatty acids. The major cellular fatty acids $(>4 \%)$ are iso- $\mathrm{C}_{16: 0}$, anteiso- $\mathrm{C}_{15: 0}$, iso- $\mathrm{C}_{14: 0}$, iso- $\mathrm{C}_{16: 1} \mathrm{H}$, anteiso- $\mathrm{C}_{17: 0}$ and iso- $\mathrm{C}_{15: 0}$. No antimicrobial activity is detected against Escherichia coli ATCC 25922, Pseudomonas aeruginosa ATCC 6538, Bacillus subtilis ATCC 6633, Candida albicans ATCC 10231 or Penicillium citrinum AS 3.2788. The DNA $\mathrm{G}+\mathrm{C}$ content of the type strain is $72.94 \mathrm{~mol} \%$.

The type strain, GIMN4.003 ${ }^{\mathrm{T}} \quad\left(=\mathrm{CCTCCM} \quad 208215^{\mathrm{T}}\right.$ $=$ NRRL B-24801 ${ }^{\mathrm{T}}$ ), was isolated from seawater.

\section{Acknowledgements}

This work was supported by the International S\&T Cooperation Program of China (project no. 2008DFA31560), the Guangdong Ministry of Science and Technology, PR China (project no. 2009B050300003), and the Guangzhou Science and Technology Program (project no. 2008J1-C091).

\section{References}

Altschul, S. F., Madden, T. L., Schäffer, A. A., Zhang, J., Zhang, Z., Miller, W. \& Lipman, D. J. (1997). Gapped BLAST and PSI-BLAST: a new generation of protein database search programs. Nucleic Acids Res 25, 3389-3402.

Atlas, R. M. (1993). Handbook of Microbiological Media. Edited by L. C. Parks. Boca Raton, FL: CRC Press.

Balagurunathan, R. (2004). Marine actinomycetes: a promising future of pharmaceutical industry. Adv Biotechnol 20, 16-20.

Butte, W. (1983). Rapid method for the determination of fatty acid profiles from fats and oils using trimethylsulphonium hydroxide for transesterification. J Chromatogr A 261, 142-145.

Collins, M. D., Pirouz, T., Goodfellow, M. \& Minnikin, D. E. (1977). Distribution of menaquinones in actinomycetes and corynebacteria. J Gen Microbiol 100, 221-230.

Cui, X. L., Mao, P. H., Zeng, M., Li, W. J., Zhang, L. P., Xu, L. H. \& Jiang, C. L. (2001). Streptimonospora salina gen. nov., sp. nov., a new member of the family Nocardiopsaceae. Int J Syst Evol Microbiol 51, 357-363.

De Ley, J., Cattoir, H. \& Reynaerts, A. (1970). The quantitative measurement of DNA hybridization from renaturation rates. Eur $J$ Biochem 12, 133-142.

Edwards, U., Rogall, T., Blöcker, H., Emde, M. \& Böttger, E. C. (1989). Isolation and direct complete nucleotide determination of entire genes. Characterization of a gene coding for $16 \mathrm{~S}$ ribosomal RNA. Nucleic Acids Res 17, 7843-7853.

Hasegawa, T., Takizawa, M. \& Tanida, S. (1983). A rapid analysis for chemical grouping of aerobic actinomycetes. J Gen Appl Microbiol 29, 319-322.

Jensen, P. R., Mincer, T. J., Williams, P. G. \& Fenical, W. (2005). Marine actinomycete diversity and natural product discovery. Antonie van Leeuwenhoek 87, 43-48.

Kornerup, A. \& Wanscher, J. H. (1978). Methuen Handbook of Colour, 3rd edn. London: Eyre Methuen.
Koshy, A., Dhevendaran, K., Georgekutty, M. I. \& Matarajan, P. (1997). L-Asparaginase activity in Streptomyces plicatus isolated from the alimentary canal of the fish, Gerres filamentosus (Cuvier). J Mar Biotechnol 5, 181-185.

Kroppenstedt, R. M. (1985). Fatty acid and menaquinone analysis of actinomycetes and related organisms. In Chemical Methods in Bacterial Systematics (Society for Applied Bacteriology Technical Series vol. 20), pp. 173-199. Edited by M. Goodfellow \& D. E. Minnikin. New York: Academic Press.

Kumar, S., Nei, M., Dudley, J. \& Tamura, K. (2008). MEGA: a biologistcentric software for evolutionary analysis of DNA and protein sequences. Brief Bioinform 9, 299-306.

Lechevalier, H. A. \& Lechevalier, M. P. (1970). A critical evaluation of the genera of aerobic actinomycetes. In The Actinomycetales, pp. 393405. Edited by H. Prauser. Jena: VEB Gustav Fischer.

Mandel, M. \& Marmur, J. (1968). Use of ultraviolet absorbance temperature profile for determining the guanine plus cytosine content of DNA. Methods Enzymol 12, 195-206.

Manfio, G. P., Zakrzewska-Czerwinska, J., Atalan, E. \& Goodfellow, M. (1995). Towards minimal standards for the description of Streptomyces species. Biotekhnologia 7-8, 242-263.

Nakase, T. (editor) (1992). JCM Catalogue of Strains, 5th edn. Wako: Japan Collection of Microorganisms and Life Science Research Information Section, Institute of Physical and Chemical Research.

Sabu, A. (2003). Sources, properties and applications of microbial therapeutic enzymes. Indian J Biotechnol 2, 334-341.

Saitou, N. \& Nei, M. (1987). The neighbor-joining method: a new method for reconstructing phylogenetic trees. Mol Biol Evol 4, 406425.

Sasser, M. (1990). Identification of bacteria by gas chromatography of cellular fatty acids, MIDI Technical Note 101. Newark, DE: MIDI Inc.

Schleifer, K. H. \& Kandler, O. (1972). Peptidoglycan types of bacterial cell walls and their taxonomic implications. Bacteriol Rev 36, 407-477.

Shirling, E. B. \& Gottlieb, D. (1966). Methods for characterization of Streptomyces species. Int J Syst Bacteriol 16, 313-340.

Thompson, J. D., Higgins, D. G. \& Gibson, T. J. (1994). ClustaL W: improving the sensitivity of progressive multiple sequence alignment through sequence weighting, position-specific gap penalties and weight matrix choice. Nucleic Acids Res 22, 4673-4680.

Waksman, S. A. (1961). Classification, Identification and Descriptions of Genera and Species (The Actinomycetes, vol. 2). Baltimore: Williams \& Wilkins.

Wayne, L. G., Brenner, D. J., Colwell, R. R., Grimont, P. A. D., Kandler, O., Krichevsky, M. I., Moore, L. H., Moore, W. E. C., Murray, R. G. E. \& other authors (1987). Report of the ad hoc committee on reconciliation of approaches to bacterial systematics. Int J Syst Bacteriol 37, 463-464.

Williams, S. T., Goodfellow, M., Alderson, G., Wellington, E. M. H., Sneath, P. H. A. \& Sackin, M. J. (1983). Numerical classification of Streptomyces and related genera. J Gen Microbiol 129, 1743-1813.

Williams, S. T., Goodfellow, M. \& Alderson, G. (1989). Genus Streptomyces Waksman and Henrici 1943, 339 ${ }^{\mathrm{AL}}$. In Bergey's Manual of Systematic Bacteriology, vol. 4, pp. 2452-2492. Edited by S. T. Williams, M. E. Sharpe \& J. G. Holt. Baltimore: Williams \& Wilkins.

Xiao, J., Wang, Y., Luo, Y. X., Xie, S. J., Ruan, J. S. \& Xu, J. (2009). Streptomyces avicenniae sp. nov., a novel actinomycete isolated from the rhizosphere of the mangrove plant Avicennia mariana. Int J Syst Evol Microbiol 59, 2624-2628. 